\title{
Wheat Genes Encoding Two Types of PR-1 Proteins Are Pathogen Inducible, but Do Not Respond to Activators of Systemic Acquired Resistance
}

\author{
Antonio Molina, Jörn Görlach, Sandra Volrath, and John Ryals \\ Biotechnology and Genomics Center, Novartis Crop Protection Inc., Research Triangle Park, NC 27709- \\ 2257, U.S.A. \\ Accepted 4 October 1998.
}

\begin{abstract}
Wheat cDNAs that encode proteins PR-1.1 and PR-1.2 were cloned. Deduced amino acid sequences were homologous to those of pathogen-induced, basic PR-1 proteins from plants. Although expression of PR1.1 and PR1.2 genes was induced upon infection with either compatible or incompatible isolates of the fungal pathogen Erysiphe graminis, these genes did not respond to activators of systemic acquired resistance (SAR), such as salicylic acid (SA), benzothiadiazole (BTH), or isonicotinic acid (INA).
\end{abstract}

Additional keywords: induced resistance, monocots, pathogenesis-related (PR) proteins, WCI genes.

The accumulation of pathogenesis-related (PR) proteins is one of the best-characterized plant defense responses. It occurs after pathogen attack at a faster rate in incompatible than in compatible interactions (Kombrink and Somssich 1997; Hammond-Kosack and Jones 1996). In some dicots, such as tobacco and Arabidopsis thaliana, the induction of PR proteins tightly correlates with the onset of a broad-spectrum, systemic resistance, generally designated systemic acquired resistance (SAR; Ward et al. 1991; Uknes et al. 1992; Ryals et al. 1996). SAR can be activated by necrotic lesions, whether these are formed as part of the hypersensitive response (HR) in a incompatible interaction or as a symptom of disease in a compatible interaction (Ryals et al. 1996). SAR can also be elicited by exogenous treatments with chemical inducers, such as salicylic acid (SA), 2,6-dichloro isonicotinic acid (INA), or benzo(1, 2, 3)thiadiazole-7-carbothioic acid S-methyl ester (BTH; Ward et al. 1991; Uknes et al. 1992; Vernooij et al. 1995; Friedrich et al. 1996; Lawton et al. 1996). Endogenous SA plays

Corresponding author: A. Molina; Telephone: 34-91-3365709; Fax: 3491-3365757; E-mail: molina@bit.etsia.upm.es

Present address of Antonio Molina: Laboratorio de Bioquímica y Biología Molecular, Departamento de Biotecnología-UPM, E.T.S.I. Agrónomos, Ciudad Universistaria s/n, 28040-Madrid, Spain

Present address of Jörn Görlach and John Ryals: Paradigm Genetics, P.O. Box 14528, Research Triangle Park, NC 27709-4528, U.S.A.

Nucleotide and/or amino acid sequence data are to be found at the EMBL data base as accession numbers AJ007348 (PR1.1) and AJ007349 (PR1.2). a critical role in the activation of SAR, and its levels increase after pathogen infection prior to the induction of $\mathrm{PR}$ proteins (Malamy et al. 1990; Métraux et al. 1990). Depletion of SA in plants results in a breakdown of both SAR and gene-for-gene resistance (Gaffney et al. 1993; Delaney et al. 1994; Bi et al. 1995; Mauch-Mani and Slusarenko 1996; Pallas et al. 1997).

Although expression patterns of $P R$ genes vary among different plant species (Ryals et al. 1996), the induction of genes $P R 2, P R 5$, and, particularly, $P R 1$ by pathogens and chemicals occurs in most dicots, and consequently these genes have often been used as markers of SAR onset (Ward et al. 1991; Uknes et al. 1992; Friedrich et al. 1996; Lawton et al. 1996). In monocots, several homologues of the dicot $P R$ genes have been identified. In particular, $P R I$ and $P R 5$ homologues have been characterized in maize and barley, and found to be induced in both incompatible and compatible interactions (Casacuberta et al. 1991; Hahn et al. 1993; Muradov et al. 1993; Bryngelsson et al. 1994; Stevens et al. 1996; Morris et al. 1998). The expression of genes encoding basic PR-1 from barley and acidic PR-1 from maize has also been shown to be induced after plant treatment with INA and BTH, respectively (Muradov et al. 1993; Kogel et al. 1994; Morris et al. 1998).

Pathogen-induced resistance has been reported in monocots, although its significance under field conditions is unclear (Ouchi et al. 1974; Horino 1976; Schweizer et al. 1989; Smith and Métraux 1991; Hwang and Heitefuss 1992). It has also been shown that chemical inducers, including INA and BTH, can also activate resistance in monocots (Watanabe et al. 1979; Kogel et al. 1994; Görlach et al. 1996; Morris et al. 1998). In wheat, although SAR has not been conclusively demonstrated, it has been reported that both biologically and chemically induced resistance can be established after Erysiphe graminis infection or treatment with BTH (Schweizer et al. 1989; Kmecl et al. 1995; Görlach et al. 1996). The expression of different sets of wheat genes has been correlated either with the establishment of pathogen-induced resistance (i.e., WIR genes; Kmecl et al. 1995) or chemically induced resistance (i.e., WCI genes; Görlach et al. 1996).

To investigate the expression pattern of $P R l$ genes in wheat, we first cloned PR-1 cDNAs by screening at $65^{\circ} \mathrm{C}$ a leafcDNA library (Görlach et al. 1996) with, as probe, the polymerase chain reaction (PCR)-amplified sequence of the 
open reading frame of the barley PR-1b cDNA (Bryngelsson et al. 1994). Sequence analysis (Sanger et al. 1977) of the eight clones that were selected showed that, although all of them corresponded to different genes, only two proteins were represented (four clones each), i.e., PR-1.1 and PR-1.2. These proteins were homologous to previously reported basic PR-1 proteins from other plant species, and their open reading frames included typical signal peptide sequences, 24 amino acids in length (Fig. 1A). Mature protein PR-1.1 (14,983 Da) was basic ( $\mathrm{pI}=8.55)$, and its sequence was 93 to $96 \%$ identical to those previously described for basic PR-1 proteins from barley (Muradov et al. 1993; Bryngelsson et al. 1994; Mouradov et al. 1994), and was more distantly related (72 to $76 \%$ identical residues) to proteins PRm from maize (Casacuberta et al. 1991) and PR-1 from rice (GenBank accession no. U89895) (Fig. 1A). The putative mature protein PR-1.2
$(16,314 \mathrm{Da})$ was not basic $(\mathrm{pI}=7.05)$, and its sequence was closely related ( $94 \%$ identical residues) to that of the barley BPR-1 protein (Stevens et al. 1996). PR-1.2 and BPR-1 had a C-terminal extension (9 amino acids in length in PR-1.2), absent in PR-1.1 and its homologues, that could represent a vacuolar targeting signal (Stevens et al. 1996; Fig. 1A). Although both wheat PR-1 proteins were highly homologous (67\% identical residues), they represent two different PR-1 protein types (Fig. 1A). A clear divergence between PR-1.1 and PR-1.2 and between basic monocot and acid dicot PR-1 proteins is shown in the phylogenetic tree represented in Figure 1B.

Southern blot analysis was carried out (Ausubel et al. 1994) with genomic DNA from the hexaploid wheat cv. Kanzler, purified as previously described (Molina et al. 1996), and with as probes the complete inserts of clones pWPR1.1a and pWPR1.2a, respectively encoding PR-1.1 and PR-1.2 pro-

A

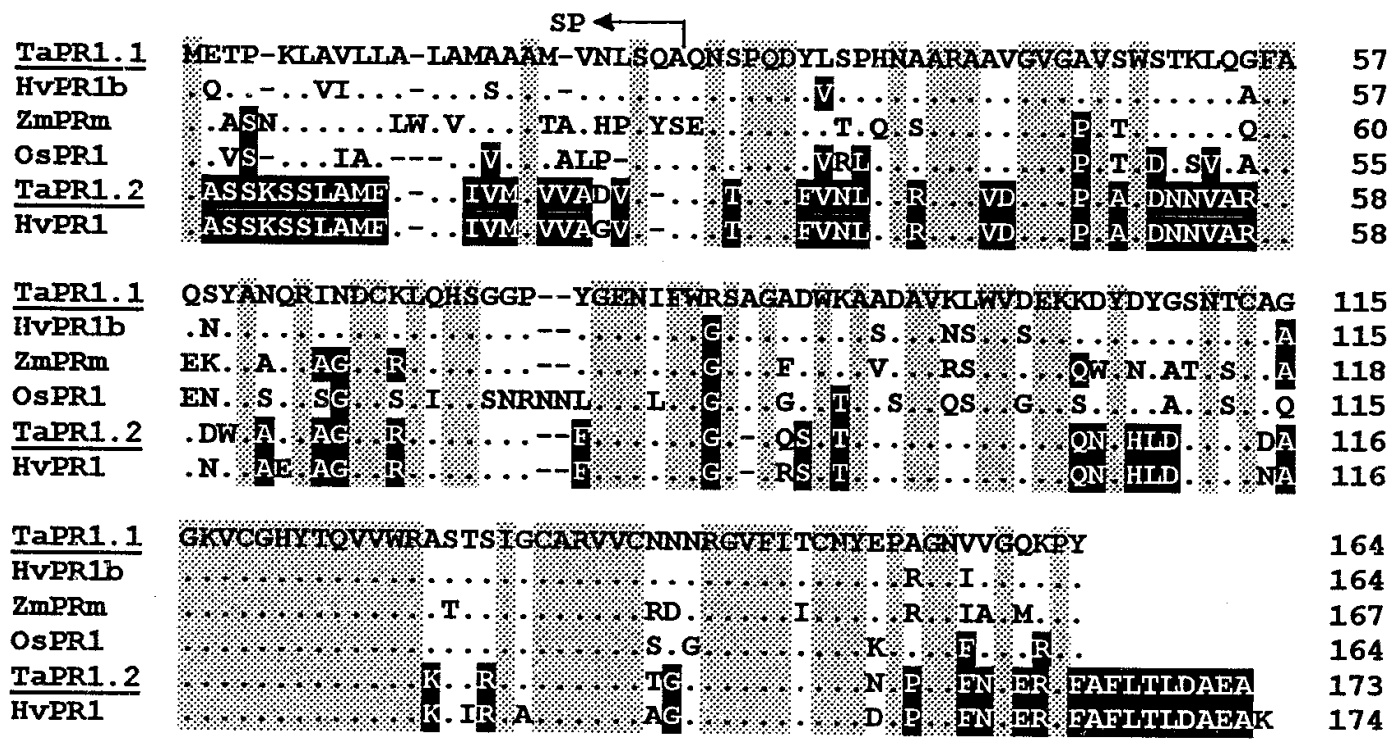

B

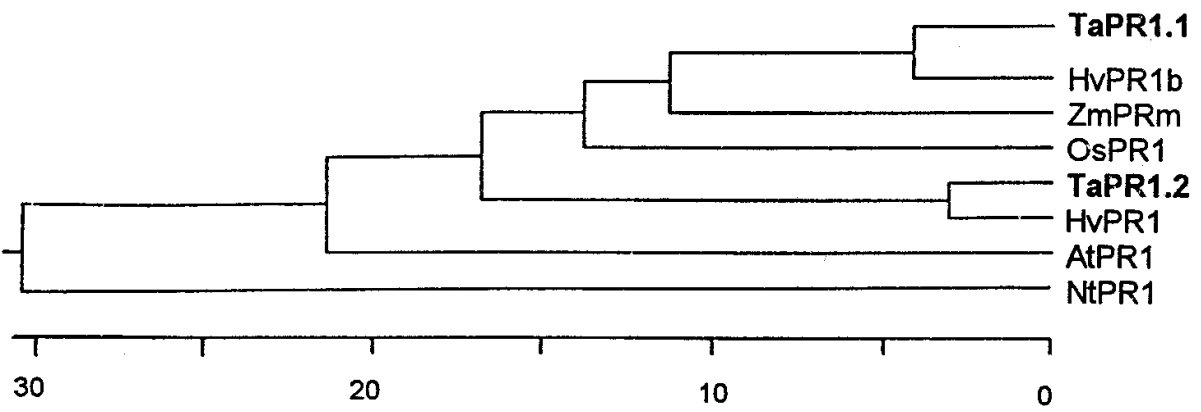

Fig. 1. Two types of PR-1 proteins are present in wheat. A, Alignment of the deduced amino acid sequences of wheat PR-1.1 protein (TaPR1.1) with PR1 proteins from barley (HvPR1b; Bryngelsson et al. 1994), maize (ZmPRm; Casacuberta et al. 1991), rice (OsPR; GenBank accession no. U89895), the deduced amino acid sequence of wheat PR-1.2 (TaPR1.2), and protein BPR-1 from barley (HvPR1; Stevens et al. 1996). Amino acids identical to those of wheat PR-1.1 are dotted; amino acids conserved in all the proteins aligned are shaded (gray). Amino acids identical to those of TaPR-1.2 are shaded (black). Gaps introduced to optimize alignment are represented by dashes. Signal peptide (SP) is indicated. B, Phylogenetic tree of mature proteins PR1.1 and PR-1.2 from wheat, monocot PR-1 proteins described in A, and PR-1 proteins from the dicots species Arabidopsis thaliana (AtPR1; Uknes et al. 1992), and Nicotiana tabacum (NtPR1; Pfitzner and Goodman 1987). Scale represents mean number of differences per residues along each branch. Alignment and phylogenetic tree were carried out with the CLUSTAL 4.0 program (Thompson et al. 1994). 
teins. Under the high stringency conditions used $\left(65^{\circ} \mathrm{C}\right.$; Church and Gilbert 1984), these probes did not crosshybridize (not shown). The multiplicity of hybridization bands shown in Figure 2 was congruent with the heterogeneity of cDNAs encoding each protein and the allohexaploid nature of wheat. In barley and maize, several PRl genes have also been identified (Casacuberta et al. 1991; Muradov et al. 1993; Bryngelsson et al. 1994; Mouradov et al. 1994; Morris et al. 1998).

To investigate the expression of the two classes of $P R 1$ genes in wheat, total RNA was extracted from different organs (Lagrimini et al. 1987) and a Northern (RNA) blot analysis was carried out (Ausubel et al. 1994). A weak PR1.1 hybridization signal was detected in whole seedlings and in the roots of adult plants, whereas the PRI.2 signal was strong in seedlings and adult roots, and weaker in leaves (Fig. 3). No signal was detected for either type of gene in pistils and anthers (Fig. 3). The four different cDNAs per gene type that we have cloned indicate that at least four genes per PRI type are expressed; thus, our data corresponded to the overall expression of each gene type.

To investigate if PRI.1 and PRl.2 genes had the pathogeninducible expression pattern previously described for other plant PR1 genes, Northern blot analysis was carried out with total RNA extracted from wheat plants (cv. Kanzler) that had been inoculated with compatible or incompatible isolates of the fungus $E$. graminis, and from noninoculated plants (Görlach et al. 1996). Though expression of PRl.1 and PR1.2 genes was induced by both the incompatible (E. graminis $\mathrm{f}$. sp. hordei) and compatible (E. graminis f. sp. tritici) isolates

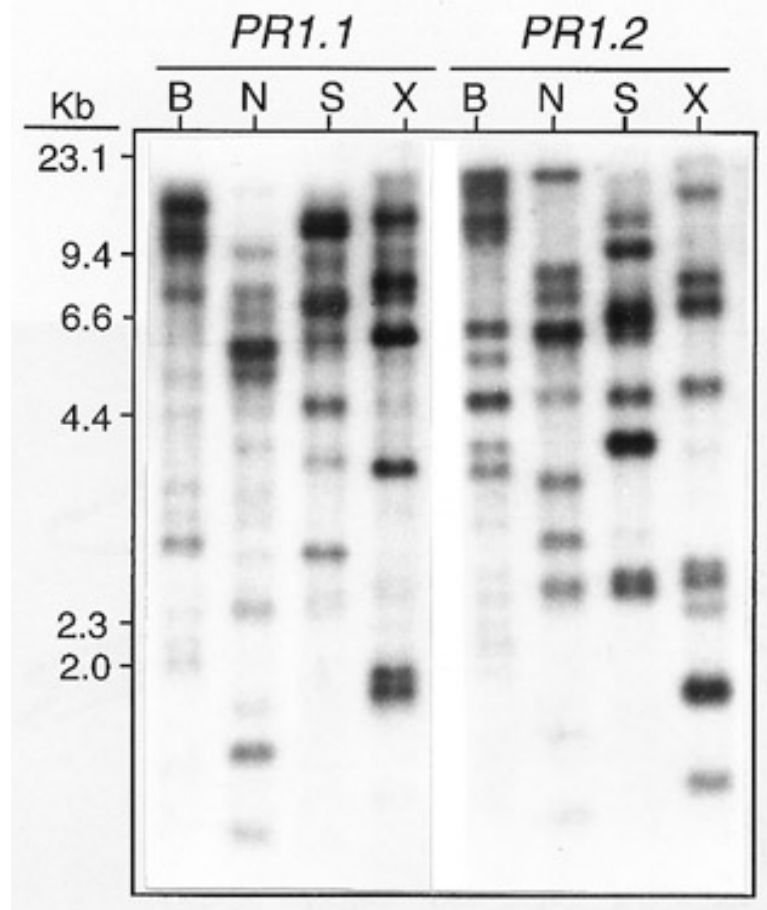

Fig. 2. Heterogeneity of $P R 1.1$ and $P R 1.2$ genes in the wheat hexaploid genome. Southern blot analysis of genomic DNA $(10 \mu \mathrm{g})$ from hexaploid wheat digested with nucleases $\operatorname{BamHI}(\mathrm{B}), \operatorname{Nco} \mathrm{I}(\mathrm{N}), \operatorname{SacI}(\mathrm{S})$, and $\mathrm{XbaI}(\mathrm{X})$. Complete insert of cDNAs clones pWPR1.1a and pWPR1.2a, corresponding to PR1.1 and PR1.2 genes, was labeled with ${ }^{32} \mathrm{P}$-dATP (random primer synthesis kit; Gibco BRL, Gaithersburg, MD), and used as probes. Markers used to deduce fragment sizes were fragments of $\lambda$ phage digested with nucleases EcoRI and HindIII. of the fungus, the induction of $P R 1.1$ genes was stronger and faster than that of $P R 1.2$ genes (Fig. 4). The observed induction of $P R 1.1$ and $P R 1.2$ genes was similar to that previously reported for $P R$ genes from other species, including those encoding both basic and acidic PR-1 proteins (Casacuberta et al. 1991; Ward et al. 1991; Uknes et al. 1992; Hahn et al. 1993; Muradov et al. 1993; Bryngelsson et al. 1994; Stevens et al. 1996; Morris et al. 1998). PRl.2 genes represented the first described monocot $P R 1$ genes with constitutive and pathogeninducible expression in leaves. Because probes used could not distinguish among variants within each gene type, it could not be confirmed if the observed inductions were due to changes in the expression pattern of one or more of the genes of a given type. It has been previously shown that monocot genes belonging to the same family and encoding the same protein can be differentially regulated by pathogens (Molina et al. 1996).

To investigate if expression of $P R 1.1$ and $P R 1.2$ genes was affected by SAR activators, wheat plants were treated with SA (3 mM), INA (0.3 mM), and BTH $(0.3 \mathrm{mM})$ (Görlach et al. 1996). Northern blot analysis of the total RNA extracted from the different treatments showed that expression of PR1.1 and $P R 1.2$ genes was not altered by these chemicals, whereas that of WCI1, a BTH-inducible gene used as control (Görlach et al. 1996), was induced (Fig. 5). It has been previously shown that expression of WCI genes tightly correlates with the induced resistance observed after treatment of wheat plants with BTH (Görlach et al. 1996).

It has been reported that pretreatment of plants with SAR activators before pathogen infection can enhance plant defense responses by a mechanism that seems to be SA dependent (Kauss et al. 1992; Mur et al. 1996; Shirasu et al. 1997; Kästner et al. 1998; Thulke and Conrath 1998). This effect potentiates the induction of some $P R$ genes, such as $P R 10$ in asparagus and parsley, class III chitinase in cucumber, and the SARassociated gene PRI in A. thaliana (Mur et al. 1996; Kästner et al. 1998; Thulke and Conrath 1998; A. Molina and J. Ryals, unpublished). To investigate whether PR1 genes are under this regulatory control, wheat plants (cv. Rialto) were treated with $0.3 \mathrm{mM}$ BTH 3 days before inoculation with $E$. graminis $\mathrm{f}$. sp. tritici, and PRI expression was analyzed and compared with

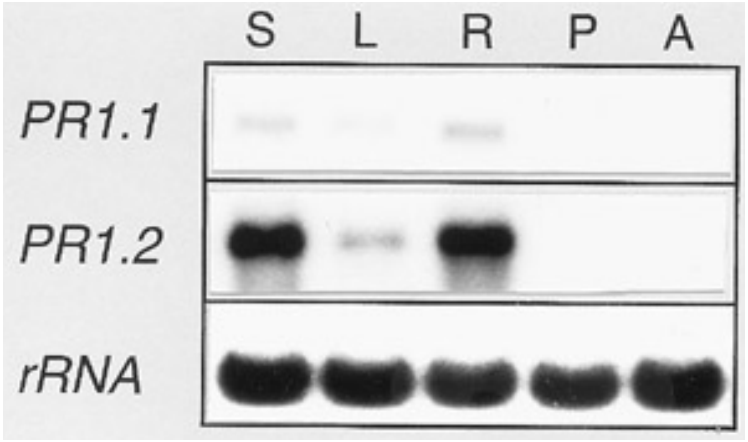

Fig. 3. Expression of $P R 1.1$ and $P R 1.2$ genes in different wheat tissues. Northern (RNA) blot analysis of total RNAs (2 $\mu \mathrm{g}$ per lane) collected from whole seedlings (S), adults leaves (L) and roots (R), pistils (P), and anthers (A). RNA was transferred to Nylon membranes (GeneScreen Plus; Du Pont-New England Nuclear, Boston) following standard procedures (Ausubel et al. 1994), and blot was hybridized with probes indicated in Figure 2. RNA equal loading was checked by hybridization of the blot with a probe corresponding to the wheat $25 \mathrm{~S}$ ribosomal RNA (rRNA). This was one of three experiments with identical results. 
that of wheat plants that had been inoculated only with the fungus. Northern blot analysis of total RNA extracted at different days before and after fungal inoculation showed that the expression patterns of PRI.1 and PRI.2 genes in plants that have been treated with BTH prior to inoculation are identical to that of plants that had not been pretreated (not shown). These results confirmed that the regulation of wheat PRI genes by chemicals differs from that previously described for PRl genes from dicot and other monocot species, such as barley and maize (Ward et al. 1991; Uknes et al. 1992; Kogel et al. 1994; Friedrich et al. 1996; Lawton et al. 1996; Morris et al. 1998).

In dicots, some genes, including $P R l$, are induced whether SAR is triggered by pathogens or by chemicals (Ward et al. 1991; Uknes et al. 1992; Friedrich et al. 1996; Lawton et al. 1996). In wheat, although SAR has not been conclusively demonstrated, pathogen-induced or chemically induced resistance has been reported, and the expression of two different sets of genes (WIR and WCI) has been found to be tightly correlated with the establishment of the induced resistance (Schweizer et al. 1989; Kmecl et al. 1995; Görlach et al. 1996). Interestingly, the pathogen-inducible expression patterns of WIR genes in wheat and $P R I$ genes in dicots are very similar, but the former do not respond to SAR activators (Schaffrath et al. 1997). Conversely, the chemically inducible expression pattern of $W C I$ genes in wheat resembles that of

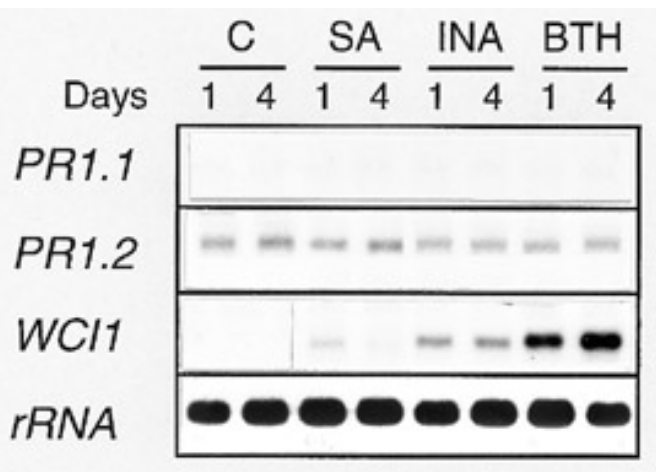

Fig. 5. $P R 1.1$ and $P R 1.2$ genes do not respond to systemic acquired resistance (SAR) activators. Northern (RNA) blot of total RNA ( $2 \mu \mathrm{g}$ per lane) extracted from leaves of wheat plants treated with wettable powder (Mock), salicylic acid (SA; $3 \mathrm{mM}$ ), 2,6-dichloro isonicotinic acid (INA; $0.3 \mathrm{mM}$ ), or benzo $(1,2,3)$ thiadiazole-7-carbothioic acid S-methyl ester (BTH; $0.3 \mathrm{mM}$ ). Blots were hybridized with PR1.1 and PR1.2 probes indicated in Figure 2, and a probe corresponding to the wheat chemically induced gene WCII (Görlach et al. 1996). Representative days (1 and 4) are showed. Induction of $P R I$ genes was not observed through the 12 days of experiment. Blots were hybridized with probes indicated in Figure 2. RNA equal loading was checked by hybridization of the blot with a probe corresponding to the wheat $25 \mathrm{~S}$ ribosomal RNA (rRNA). This was one of three experiments with identical results.

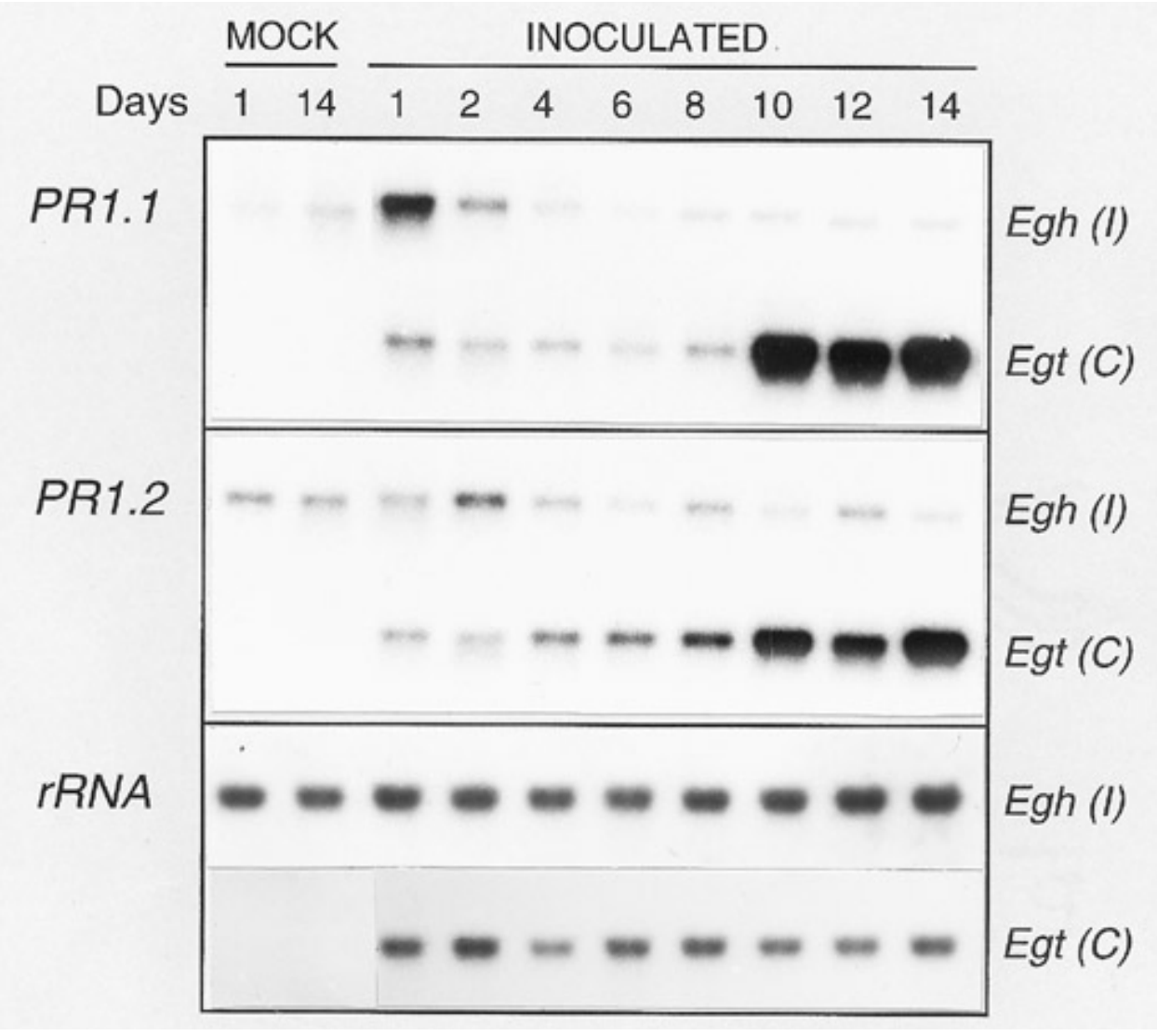

Fig. 4. Expression of $P R 1.1$ and $P R 1.2$ genes is induced by compatible and incompatible isolates of Erysiphe graminis. Northern (RNA) blot analysis of total RNA ( $2 \mu \mathrm{g}$ per lane) extracted from wheat leaves at different days after inoculation with the incompatible (I) fungus E. graminis f. sp. hordei (Egh) or the compatible (C) fungus E. graminis f. sp. tritici (Egt). Representative samples corresponding to plants that had not been inoculated are showed (Mock, days 1 and 14). Blots were hybridized with probes indicated in Figure 2. RNA equal loading was checked by hybridization of the blot with a probe corresponding to the wheat $25 \mathrm{~S}$ ribosomal RNA (rRNA). This was one of three experiments with identical results. 
PR1 genes in tobacco and A. thaliana, although WCI genes are induced to some extent by pathogens (Ward et al. 1991; Uknes et al. 1992; Friedrich et al. 1996; Görlach et al. 1996; Lawton et al. 1996). In contrast to dicots, in wheat it seems that $P R 1$ genes are not markers of induced resistance. The lack of response of wheat PRl genes to chemical inducers is in agreement with this hypothesis.

\section{ACKNOWLEDGMENTS}

We thank Francisco García-Olmedo for critically reading the manuscript. The technical help of J. García and D. Lamoneda is also acknowledged. A. M. was supported by a postdoctoral fellowship from the Ministerio de Educación y Ciencia (Spain).

\section{LITERATURE CITED}

Ausubel, F. M., Brent, R., Kingston, R. E., Moore, D. D., Seidman, J. G., Smith, J. A., and Struhl, K., eds. 1994. Current Protocols in Molecular Biology. Wiley Interscience, New York.

Bi, Y.-M., Kenton, P., Mur, L., Darby, R., and Draper, J. 1995. Hydrogen peroxide does not function downstream of salicylic acid in the induction of PR protein expression. Plant J. 8:235-245.

Bryngelsson, T., Sommer-Knudsen, J., Gregersen, P. L., Collinge, D. B., Ek, B., and Thordal-Christensen, H. 1994. Purification, characterization, and molecular cloning of basic PR-1-type pathogenesis-related proteins from barley. Mol. Plant-Microbe Interact. 7:267-275.

Casacuberta, J. M., Puigdomènech, P., and San Segundo, B. 1991. A gene coding for a basic pathogenesis-related (PR-like) protein from Zea mays. Molecular cloning and induction by a fungus (Fusarium moniliforme) in germinating maize seeds. Plant Mol. Biol. 16:527536.

Church, G. M., and Gilbert, W. 1984. Genomic sequencing. Proc. Natl. Acad. Sci. USA 81:1991-1995.

Delaney, T. P, Uknes, S., Vernooij, B., Friedrich, L., Weymann, K., Negrotto, D., Gaffney, T., Gut-Rella, M., Kessmann, H., Ward, E., and Ryals, J. 1994. A central role of salicylic acid in plant disease resistance. Science 266:1247-1250.

Friedrich, L., Lawton, K., Ruess, W., Masner, P., Specker, N., Gut-Rella, M., Meier, B., Dincher, S., Staub, T., Uknes, S., Métraux, J.-P., Kessmann, H., and Ryals, J. 1996. A benzothiadiazole derivative induces systemic acquired resistance in tobacco. Plant J. 10:61-70.

Gaffney, T., Friedrich, L., Vernooij, B., Negrotto, D., Nye, G., Uknes, S., Ward, E., Kessmann, H., and Ryals, J. 1993. Requirement of salicylic acid for the induction of systemic acquired resistance. Science 261: 754-756.

Görlach, J., Volrath, S., Knauf-Beiter, G., Hengy, G., Beckhove, U., Kogel, K.-H., Oostendorp, M., Staub, T., Ward, E., Kessmann, H., and Ryals, J. 1996. Benzothiadiazole, a novel class of inducers of systemic acquired resistance, activates gene expression and disease resistance in wheat. Plant Cell 8:629-643.

Hahn, M., Jüngling, S., and Knogge, W. 1993. Cultivar-specific elicitation of barley defense reactions by the phytotoxic peptide NIP1 from Rhynchosporium secalis. Mol. Plant-Microbe Interact. 6:745-754.

Hammond-Kosack, K. E., and Jones, J. D. G. 1996. Resistance genedependent plant defense responses. Plant Cell 8:1773-1791.

Horino, O. 1976. Induction of bacterial leaf blight resistance by incompatible strains of Xanthomonas oryzae in rice. Pages 43-55 in: Biochemistry and Cytology of Plant Parasite Interactions. K. Tomiyama, J. Daly, I. Uritani, H. Oku, and S. Ouchi, eds. Kodanska, Tokyo.

Hwang, B. K., and Heitefuss, R. 1992. Induced resistance of spring barley to Erysiphe graminis f. sp. hordei. Phytopathol. Z. 103:41-47.

Kästner, B., Tenhaken, R., and Kauss, H. 1998. Chitinase in cucumber hypocotyls is induced by germinating fungal spores and by fungal elicitor in synergism with inducers of acquired resistance. Plant J. 13: 447-454.

Kauss, H., Theisinger-Hinkel, E., Mindermann, R., and Conrath, U. 1992. Dichloroisonicotininc and salicylic acid, inducers of systemic acquired resistance, enhance fungal elicitor response in parsley cells. Plant J. 2:655-660.

Kmecl, A., Mauch, F., Winzeler, M., Winzeler, H., and Dudler, R. 1995.
Quantitative field resistance of wheat to powdery mildew and defense reactions at the seedling stage: Identification of a potential marker. Physiol. Mol. Plant Pathol. 47:185-199.

Kogel, K.-H., Beckhove, U., Dreschers, J., Münch, S., and Rommé, Y. 1994. Acquired resistance in barley. Plant Physiol. 106:1269-1277.

Kombrink, E., and Somssich, I.E. 1997. Pathogenesis related proteins in plant defense. Pages 107-128 in: The Mycota V Part A, Plant Relationships. G. Carrol and P. Tudzynski eds. Spring-Verlag, Berlin.

Lagrimini, L. M., Burkhart, W., Moyer, M., and Rothstein, S. 1987. Molecular cloning of complementary DNA encoding the ligninforming peroxidase from tobacco: Molecular analysis and tissuespecific expression. Proc. Natl. Acad. Sci. USA 84:7542-7546.

Lawton, K. A., Friedrich, L., Hunt, M., Weymann, K., Delaney, T., Kessmann, H., Staub, T., and Ryals, J. 1996. Benzothiadiazole induces disease resistance in Arabidopsis by activation of the systemic acquired resistance signal transduction pathway. Plant J. 10:71-82.

Malamy, J., Carr, J. P., Klessing, D. F., and Raskin, I. 1990. Salicylic acid: A likely endogenous signal in the resistance response of tobacco to viral infection. Science 250:1002-1004.

Mauch-Mani, B., and Slusarenko, A. J. 1996. Production of salicylic acid precursors is a major function of phenylalanine ammonia-lyase in the resistance of Arabidopsis to Peronospora parasitica. Plant Cell 8: 203-212.

Métraux, J.-P., Signer, H., Ryals, J., Ward, E., Wyss-Benz, M., Gaudin, J., Raschdorf, K., Schmid, E., Blum, W., and Inverardi, B. 1990. Increase in salicylic acid at the onset of systemic acquired resistance in cucumber. Science 250:1004-1006.

Molina, A., Díaz, I., Vasil, I. K., Carbonero, P., and García-Olmedo, F. 1996. Two cold-inducible genes encoding lipid transfer protein LTP4 from barley show differential responses to bacterial pathogens. Mol. Gen. Genet. 252:162-168.

Morris, S. W., Vernooij, B., Titatarn, S., Starrett, M., Thomas, S., Wiltse, C. C., Frederiksen, R. A., Bhandhufalck, A., Hulbert, S., and Uknes, S. 1998. Induced resistance responses in maize. Mol. Plant-Microbe Interact. 7:643-658.

Mouradov, A., Mouradova, E., and Scott, K. J. 1994. Gene family encoding basic pathogenesis-related 1 proteins in barley. Plant Mol. Biol. 26:503-507.

Mur, L. A. J., Naylor, G., Warner, S. A. J., Sugars, J. M., White, R. F., and Draper, J. 1996. Salicylic acid potentiates defence gene expression in tissue exhibiting acquired resistance to pathogen attack. Plant J. 9:559-571.

Muradov, A., Petrasovits, L., Davidson, A., and Scott, K. J. 1993. A cDNA clone for pathogenesis-related protein 1 from barley. Plant Mol. Biol. 23:439-442.

Ouchi, S., Oku, H., Hibino, C., and Aldyama, I. 1974. Induction of accessibility and resistance in leaves of barley by some races of Erysiphe graminis. Phytopathol. Z. 79:24-34.

Pallas, J. A., Pavia, N. L., Lamb, C., and Dixon, R. A. 1997. Tobacco plants epigenetically suppressed in phenylalanine ammonia-lyase expression do not develop systemic acquired resistance in response to infection by tobacco mosaic virus. Plant J. 10:281-293.

Pfitzner, U. M., and Goodman, H. M. 1987. Isolation and characterization of cDNA clones encoding pathogenesis-related proteins from tobacco mosaic virus infected tobacco plants. Nucleic Acid Res. 15: 4449-4465.

Ryals, J. A., Neuenschwander, U. H., Willits, M. G., Molina, A., Steiner, H.-Y., and Hunt, M. D. 1996. Systemic acquired resistance. Plant Cell 8:1809-1819.

Sanger, F., Nicklen, S., and Coulsen, A. R. 1977. DNA sequencing with chain-terminating inhibitors. Proc. Natl. Acad. Sci. USA 74:54635467.

Schaffrath, U., Freydl, E., and Dudler, R. 1997. Evidence for different signaling pathways activated by inducers of acquired resistance in wheat. Mol. Plant-Microbe Interact. 10:779-783.

Schweizer, P., Hunziker, W., and Mösinger, E. 1989. cDNA cloning, in vitro transcription and partial sequence analysis of mRNAs from winter wheat (Triticum aestivum L.) with induced resistance to Erysiphe graminis f. sp. tritici. Plant Mol. Biol. 12:643-654.

Shirasu, K., Nakajima, H., Rajasekhar, V. K., Dixon, R. A, and Lamb, C. 1997. Salicylic acid potentiates an agonist-dependent gain control that amplifies pathogen signal in the activation of defense mechanisms. Plant Cell 9:261-270.

Smith, J. A., and Métraux, J.-P. 1991. Pseudomonas syringae pv. syrin- 
gae induces systemic resistance to Pyricularia oryzae in rice. Physiol. Mol. Plant Pathol. 39:451-461.

Stevens, C., Titarenko, E., Hargreaves, J. A., and Gurr, S. J. 1996. Defence-related gene activation during an incompatible interaction between Stagonospora (Septoria) nodorum and barley (Hordeum vulgare L.) coleoptile cells. Plant Mol. Biol. 31:741-749.

Thompson, J. D., Higgins, D. G., and Gibson, T. J. 1994. CLUSTAL W: Improving the sensitivity of progressive multiple sequence alignment through sequence weighting, position-specific gap penalties and weight matrix choice. Nucleic Acid Res. 22:4673-4680.

Thulke, O., and Conrath, U. 1998. Salicylic acid has a dual role in the activation of defence-related genes in parsley. Plant J. 14:35-42.

Uknes, S., Mauch-Mani, B., Moyer, M., Potter, S., Williams, S.,
Dincher, S., Chandler, D., Slusarenko, A., Ward, E., and Ryals, J. 1992. Acquired resistance in Arabidopsis. Plant Cell 4:645-656.

Vernooij, B., Friedrich, L., Ahl Goy, P., Staub, T., Kessmann, H., and Ryals, J. 1995. 2,6-dichloroisonicotinic acid-induced resistance to pathogens without the accumulation of salicylic acid. Mol. Plant-Microbe Interact. 8:228-234.

Ward, E. R., Uknes, S. J., Williams, S. C., Dincher, S. S., Wiederhold, D. L., Alexander, D. C., Ahl-Goy, P., Métraux, J.-P., and Ryals, J. A. 1991. Coordinate gene activity in response to agents that induce systemic acquired resistance. Plant Cell 3:1085-1094.

Watanabe, T., Sekizawa, Y., Shimura, H., Suzuki, Y., Matsumoto, M., Iwata, M., and Mase, S. 1979. Effects of probenazole (Oryzemate) on rice plants with reference to controlling rice blast. J. Pestic. Sci. 4:53-59. 